\title{
IMMUNOMODULATORY EFFECTS OF BLACK CINCAU (MESONA PALUSTRIS BL.) SUPPLEMENT ON ESCHERICHIA COLI STRAIN 0157-INFECTED MICE
}

\author{
TRI DEWANTI WIDYANINGSIH*, ERRYANA MARTATI, DIAH MUSTIKA LUKITASARI
}

Department of Agricultural Product Technology, Faculty of Agricultural Technology, Brawijaya University Malang Indonesia. Email: tridewantiw@ub.ac.id

Received: 13 June 2016, Revised and Accepted: 05 May 2017

\section{ABSTRACT}

Objective: This study objective was to determine the immunomodulatory effects of the black cincau (Mesona palustris BL.) supplement on Escherichia coli strain 0157-infected mice.

Methods: Black cincau (Mesona palustris BL.) and red ginger (Zingiber officinale var. rubrum) were extracted on a pilot plant scale. For the animal experiment, the mice were adapted for 7 days with black cincau supplement at a dose of $43.29 \mathrm{mg} / \mathrm{kg}$ b.w. (SSP I), a dose of $85.58 \mathrm{mg} / \mathrm{kg}$ b.w. (SSP II), a dose of $4.33 \mathrm{mg} / \mathrm{kg}$ b.w. of a commercial immunomodulator (SK) and buffer saline for the negative control (KN) and positive control (KP). Then, mice were infected intraperitoneally (intraperitoneally) with $E$. coli strain $015710^{10} \mathrm{cfu} / \mathrm{mL}$, except KN. On day 21 , the cell of mouse spleen was analyzed using flow cytometry.

Results: Result showed that administration of black cincau supplement up to $85.58 \mathrm{mg} / \mathrm{kg}$ b.w gave immunomodulator effects in infected mice. Immunomodulator effect can be seen through the increasing of the relative average of a cluster of differentiation (CD) $4^{+} \mathrm{T}$ cells, CD $8^{+} \mathrm{T}$ cells, $\mathrm{CD} 4^{+} \mathrm{CD} 8^{+}$ $\mathrm{T}$ cells, CD4 ${ }^{+} \mathrm{CD} 62 \mathrm{~L} \mathrm{~T}$ cells, CD8 ${ }^{+} \mathrm{CD} 62 \mathrm{~L} \mathrm{~T}$ cells, and CD68 ${ }^{+}$interferon $\gamma$ (Interferon gamma) monocytes cells. Exposure of black cincau supplement on infected mice can recover small intestine mucosa structure of mice.

Conclusions: This study demonstrates that the supplement of black cincau extract can give an immunomodulatory effect on $E$. coli-infected mice.

Keywords: Black cincau, Mesona palustris BL., Red ginger, Immunomodulator, T cell, Interferon g, Escherichia coli.

(C) 2017 The Authors. Published by Innovare Academic Sciences Pvt Ltd. This is an open access article under the CC BY license (http://creativecommons. org/licenses/by/4. 0/) DOI: http://dx.doi.org/10.22159/ajpcr.2017.v10i9.13402

\section{INTRODUCTION}

The immune system is a defense process in a response of antigen which is categorized into two groups: Innate immune system and specific immune system [1]. The immune response is initiated by microorganism infection or antigen that caused macrophage binding to antigen and relaying signals to T lymphocyte [2]. Escherichia coli is predominant bacteria in contaminated foods such as meat, milk, fruits, and vegetables. Infection caused by $E$. coli occurs more often in children than adults [3]. The vaccine is a common prevention used to increase the response of mucous immune [4-6]

Imunomodulator is a compound affecting the immune response by increasing the immune system (immunostimulant) and suppressing abnormal immune system (immunosuppressant) [7]. Natural products are known to contain bioactive compounds such as antioxidant and antiinflammatory that can be used as immunomodulator [8]. Black cincau and red ginger are well known as immunomodulator agents. Black cincau and red ginger are traditionally used to prevent heatiness, fever, abdominal irritation, indigestion, hypertension, and anti-inflammatory agent [9-11]. Exposure of ginger extract orally to pregnant mouse did not show toxicity up to $1000 \mathrm{mg} / \mathrm{kg}$ b.w [12]. Consumption of fresh red ginger can cause side effects such as light diarrhea and allergy [13]. Ginger is consumed for managing body weight, anti hiperlipidemia, alzheimer, diabetes, and sea sick [13-18]

Functional beverages containing black cincau, cinnamon bark (Cinnamomum burmannii), and pandan leaves (Pandanus amaryllifolius) can increase levels of interferon- $\gamma$ (IFN- $\gamma$ ) and Ig G (Immunoglobulin G) in Salmonella thypimurium-infected mice [19]. It has been reported that exposure of water extract of black cincau in HeLa cells increased the expression of IFN- $\gamma$ and immune system activity through Natural Killer
(NK) cell, T-cell toxicity $\left(\mathrm{CD}^{+}\right)$and macrophage [10,20]. A combination of black cincau, pandan leaves, and ginger has synergy effects indicated by increasing level of total phenolic and antioxidant [21]

Most extraction of bioactive compounds in plants was performed in laboratory scale. The extract obtained might have a different activity of bioactive compound compared to those extracts obtained from a pilot plant scale. This study aimed to determine immunomodulatory effects of black cincau and red ginger extracted on a pilot plant scale compared to commercial immunomodulator that indicated by the relative average of $\mathrm{CD}^{+} \mathrm{T}$ cells, $\mathrm{CD}^{+} \mathrm{T}$ cells, CD62L T cells, monocyte (CD68), and cytokine IFN- $\gamma$ in $E$. coli strain 0157-infected mice.

\section{MATERIALS AND METHODS}

\section{Materials}

Dried leaves of black cincau (janggelan) were obtained from Magetan, East Java, Indonesia. Dried red ginger and dextrin were purchased from local markets in Malang East Java, Indonesia. Fetal calvin serum (FCS) "Gibco" was obtained from Parasitology Laboratory, Brawijaya University, Malang. Non-sterile phosphate buffered saline (PBS) was obtained from Biomedical Laboratory, Brawijaya University, Indonesia. FACSFlow BD was purchased from Animal Physiology Laboratory, Brawijaya University, Indonesia. "Biolegend" antibody (fluorescein isothiocyanate [FITC]-conjugate rat anti-mouse CD4 clone GK1.5, PE-conjugate rat anti-mouse CD8 clone 53-6.7, PE/Cy5-conjugate rat anti-mouse CD62L clone MEL-14, FITC-conjugate rat anti-mouse CD68 clone FA-11, and PE/Cy5 conjugate rat anti-mouse IFN- $\gamma$ clone XMG 1.2) was obtained from Animal Physiology Laboratory Brawijaya University, Malang; ethanol 70\% and 96\%, and formalin 37\% were purchased from Makmur Sejati Store Malang. E. coli strain 0157 was obtained from the Microbiology Laboratory Faculty of Medicine, Brawijaya University 
Malang. Male white mice (Mus musculus) Balb/c aged 8-10 weeks, weight 20-30 g were obtained from Parasitology Laboratory Brawijaya University Malang.

Preparation of supplement of black cincau and red ginger

Dried leaves of janggelan and dried red ginger with ratio $24: 1(\mathrm{w} / \mathrm{w})$ were extracted with the infused water method. The extraction was performed on a pilot plant scale with a capacity of $500 \mathrm{~L}$ and with a ratio of raw material and water by $1: 20(\mathrm{w} / \mathrm{v})$. The extraction was performed for 152.44 minutes at $40^{\circ} \mathrm{C}$ and $-46 \mathrm{~cm} \mathrm{Hg}$. Then, the extract was evaporated at $50^{\circ} \mathrm{C}$ and $-60 \mathrm{~cm} \mathrm{Hg}$ for $21 \mathrm{hrs}$ until one-fifth of the initial amount. Dextrin of $5 \%$ was added to the extract. Then, the mixture was dried in the oven at $50^{\circ} \mathrm{C}$ for $21 \mathrm{hrs}$.

\section{Determination of total phenolic}

Total phenolic content was analyzed using Folin-Ciolcalteu method. In brief, $10 \mathrm{mg}$ of the supplement was diluted with distilled water, then mixed with $1 \mathrm{ml}$ of $10 \%$ Folin-Ciocalteu reagent followed by the addition of $800 \mu \mathrm{L}$ of $7.5 \% \mathrm{Na}_{2} \mathrm{CO}_{3}$. The mixture was allowed to stand for 30 minutes in the dark. The absorbance was measured at $765 \mathrm{~nm}$. Total phenolic was expressed as $\mathrm{mg}$ of caffeic acid equivalent per g sample.

Determination of 2,2-diphenyl-1-picrylhydrazyl (DPPH) free radical scavenging activity

The free radical scavenging activities of the supplement were determined using modified of Hatano et al. [22]. The supplement was diluted with distilled water to have a concentration of $4000 \mathrm{mg} / \mathrm{mL}$, then divided into a series of dilution, followed by the addition of 0.2 mM DPPH solution. After 30 minutes incubation, the absorbance was measured at $517 \mathrm{~nm}$ using Spectrophotometer UV-vis.

\section{Examination of immunomodulatory effects of black cincau supplement in mice}

The protocol of animal experiment was approved by the animal ethical committee Brawijaya University Malang Indonesia. Mice used in this study were 6 weeks old male. Mice were adapted with susupap feed and kept in a standard animal room for 7 days. During the experiment, mice were given free access to the feed and water. 35 of mice were divided into 5 groups of seven mice per group. On day 8 to 14, groups were treated as follows: Group SSP I dosed with $43.29 \mathrm{mg} / \mathrm{kg}$ b.w of supplement, group SSP II dosed with $85.58 \mathrm{mg} / \mathrm{kg}$ b.w of supplements, group SK dosed with $4.33 \mathrm{mg} / \mathrm{kg}$ b.w of commercial immunomodulator product and Group KN and KP dosed with saline buffer. On day 14, mice were intraperitoneally infected with $E$. coli of $0.2 \mathrm{~mL} /$ mouse $\left(10^{10} \mathrm{cfu} / \mathrm{mL}\right)$, except KN. On day 15 to 21 , groups of SSP I and SSP II were dosed with the same dose of supplement as on day 8 to 14. Group of KN and KP were given only saline buffer. The supplement was given by oral gavage with the volume gavage did not exceed $6.6 \mathrm{~mL} / \mathrm{kg}$ b.w.

\section{Isolation of spleen cells}

The method of spleen cell isolation was adopted from Widyaningsih et al. with slight modification [10]. In brief, mouse spleen was placed in a petri dish containing non-sterile PBS on ice gell, and chopped with a needle. Spleen extract was filtered with stringer cell. The filtrate was transferred to a $15 \mathrm{~mL}$ tube, then added to non-sterile PBS. The filtrate was centrifuged at $1500 \mathrm{rpm}$ for 5 minutes, and then the supernatant was removed. This step was repeated twice. Pellets were added with 2\% FCS in PBS and transferred to Eppendorf tubes.

\section{Cells measurement by flow cytometry}

A flow cytometry was used to determine certain cell features as described by Zumrotul et al. [23]. Pellets were centrifuged at $5000 \mathrm{rpm}$ $4^{\circ} \mathrm{C}$ for 10 minutes, the supernatant was removed. The pellet was added with $0.4 \mathrm{~mL} \mathrm{PBS}$ and $0.1 \mathrm{~mL}$ primary antibody (CD4 FITC conjugate, CD8 PE conjugate, CD62L PE-Cy 5 conjugate, CD68 FITC conjugate, and IFN- $\gamma$ PE-Cy 5 conjugate). Samples were incubated afterward for 15 minutes on ice. Samples were added with $300 \mu \mathrm{l}$ PBS and analyzed using flow cytometer"BD FACSCalibur." Data obtained was analyzed using BD cellquest Pro $^{\mathrm{TM}}$.

\section{Histopathology of small intestine}

The small intestine was cut and placed into formaldehyde $10 \%$ suspension with PBS. Fixation of the tissue was performed with formaldehyde solution for $24 \mathrm{~h}$, washed with running water for $1 \mathrm{hr}$, then put in Automatic Tissue Tex Processor machine "Sakura Tissue Tek Xpress X 50". Afterward, samples were placed in a block with paraffin. Samples were cut with thickness 3-5 $\mu$ by microtome "LEICA RM 2245", then put in the oven $70-80^{\circ} \mathrm{C}$ for 30 minutes. Samples were put in xylol solution for 20 minutes, in ethanol for 3 minutes, and running water for 15 minutes. Samples were put in Harris Hematoxilin for 10-15 minutes for staining process. Afterward, the samples were washed with running water for 15 minutes. Samples were dyed with acid ethanol $1 \%$, ammonia, and eosin solution for 10-15 minutes. Afterward, samples were dehydrated again with ethanol for 12 minutes then clearing with xylol solution for $2 \mathrm{hrs}$.

\section{Analysis data}

Antioxidant activity and relative cell in spleen extract were statistically analyzed with One Way ANOVA using SPSS software, followed by post-hoc Tukeys (honest significant difference) test. The values of $p<0.05$ were considered statistically significant. Histopathology of the small intestine is done descriptively.

\section{RESULTS}

Total phenolic and DPPH free radical scavenging activity of black cincau supplement

Total phenolic of black cincau supplement was higher than those of raw material of black cincau and red ginger. IC50 of the supplement of black cincau is the lowest one compared to raw material and commercial immunomodulator (Table 1)

\section{Average relative cell in spleen CD $4^{+}$T cells}

The relative amount of $\mathrm{CD} 4^{+}$cells each treatment is $\mathrm{KN}(2.742 \pm 0.185)$, KP (3.374 \pm 0.175$)$, SSP I ( $5.128 \pm 0.521)$, SSP II $(2.58 \pm 0.408)$, and SK (3.514 \pm 0.533 ) (Fig. 1a). Examination of $\mathrm{CD}^{+} \mathrm{T}$ cells showed significant difference among treatments. A relative cells average of SSP I showed a cells average of $\mathrm{CD}^{+} \mathrm{T}$ cells was higher than KP. Levels of the relative average of $\mathrm{CD} 4^{+} \mathrm{T}$ cells on SSP II approached KN.

\section{$\mathrm{CD}^{+} 8 \mathrm{~T}$ cells}

The relative $\mathrm{CD}^{+}$cells of each treatment are KN (35.71 \pm 2.43 ), KP (28.16 \pm 2.67$)$, SSP I $(30.94 \pm 2.61)$, SSP II $(18.60 \pm 2.82)$ and SK (17.52 \pm 2.24 ) (Fig. 1a). Examination of $\mathrm{CD}^{+} \mathrm{T}$ cells showed significant difference among treatments. The relative average of $\mathrm{CD}^{+} \mathrm{T}$ cells showed higher numbers than the relative average of $\mathrm{CD} 4^{+} \mathrm{T}$ cells.

\section{$C D 4^{+} C D 8^{+}$T cells}

$\mathrm{CD}^{+}{ }^{+} \mathrm{CD} 8^{+} \mathrm{T}$ cells showed correlation between $\mathrm{CD}^{+}$and $\mathrm{CD} 8^{+} \mathrm{T}$ cells in lymph cells. The relative average of $\mathrm{CD} 4^{+} \mathrm{CD}^{+} \mathrm{T}$ cells of each treatment is $\mathrm{KN}(0.898 \pm 0.131)$, KP $(0.754 \pm 0.163)$, SSP I $(0.978 \pm 0.094)$, SSP II (0.708 \pm 0.132$)$, and SK (0.644 \pm 0.069$)$ (Fig. 1a).

Table 1: Total phenolic content and $\mathrm{IC}_{50}$ of raw material of black cincau and red ginger, black cincau supplement, and commercial immunomodulator

\begin{tabular}{lll}
\hline Sample & $\begin{array}{l}\text { Phenolic total } \\
\text { (mg CAE/g) }\end{array}$ & IC $_{\mathbf{5 0}}(\boldsymbol{\mu g} / \mathbf{g}) \boldsymbol{\mu g} / \mathbf{m L}$ \\
\hline Black cincau (raw material) & $15.81 \pm 0.36$ & $396.71 \pm 6.40$ \\
Red ginger (raw material) & $12.12 \pm 0.35$ & $124.99 \pm 1.36$ \\
Black cincau supplement & $66.38 \pm 1.45$ & $75.18 \pm 0.03$ \\
Commercial & $84.07 \pm 4.51$ & $251.37 \pm 7.36$ \\
immunomodulator & & \\
\hline
\end{tabular}

Data represent the mean and standard deviation of three measurements 


\section{CD4 $4^{+}$CD62L T cells}

$\mathrm{CD}^{+}{ }^{+} \mathrm{CD} 62 \mathrm{~L}$ T cells showed $\mathrm{CD} 4^{+} \mathrm{T}$ cells naive, which not encountered with specific antigen in spleen cells. The relative CD4+ CD62L T cells of each treatment are KN (1.286 \pm 0.140$)$, KP $(3.374 \pm 1.03)$, SSP I (1.198 \pm 0.217$)$, SSP II $(0.77 \pm 0.08)$, and SK $(2.096 \pm 0.203)$ (Fig. 1b). SSP II showed significant result due to the low presence of CD4 ${ }^{+}$CD62L T cells compared to other treatments. Low levels of CD4+ CD62L T cells indicated higher presence of active CD4 T cells than naïve.

\section{CD8 ${ }^{+}$CD62L T cells}

$\mathrm{CD}^{+}{ }^{+} \mathrm{CD} 62 \mathrm{~L} \mathrm{~T}$ cells showed $\mathrm{CD}^{+} \mathrm{T}$ cells naive which not encountered with specific antigen in spleen cells. The relative $\mathrm{CD} 8^{+} \mathrm{CD} 62 \mathrm{~L} \mathrm{~T}$ cells of each treatment are KN (2.51 \pm 0.59$)$, KP (1.124 \pm 0.26$)$, SSP I $(1.71 \pm 0.40)$, SSP II (0.784 \pm 0.11$)$, and SK (1.38 \pm 0.13$)$ (Fig. 1c). This study showed a relative average of CD8 $\mathrm{T}$ cells was higher than $\mathrm{CD} 8{ }^{+} \mathrm{CD} 62 \mathrm{~L}$ and $\mathrm{CD} 4 \mathrm{~T}$ cells mostly on exposure of SSP II.

\section{CD68 monocytes cells}

CD68 is a glycoprotein that expressed on monocytes. The relative CD68 monocyte of each treatment are KN (4.51 \pm 0.77$)$, KP (5.53 \pm 0.69$)$,

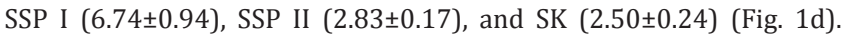
Exposure of black cincau supplement at a dose of $43.29 \mathrm{mg} / \mathrm{kg}$ b.w showed increased of monocytes cells compared to other treatments.

\section{CD68 + +IFN- $\gamma$ monocytes cells}

CD68+IFN- $\gamma$ monocytes cells showed CD68 monocytes cells that contain IFN- $\gamma$ in the membrane. The level of IFN- $\gamma$ in CD68 monocyte cells of each treatment is KN $(3.29 \pm 0.54)$, KP $(2.95 \pm 0.69)$, SSP I $(1.84 \pm 0.53)$, SK (1.82 \pm 0.37 ), and SSP II (1.59 \pm 0.41 ) (Fig. 1d). Giving supplement at a dose of $85.58 \mathrm{mg} / \mathrm{kg}$ b.w caused lower levels of IFN $-\gamma$ in CD68 monocyte cells than other treatments.

Fig. 2 shows that negative control shows good villus and the wellorganized surface of epithelial cells, cell membrane, lamina propria, and muscular mucosa. Positive control showed organized cell membrane, lamina propria, and muscularis mucosa. However, villus was shown damaged. Depleted surface epithelial cells were also present. SSP I showed more organized villus compared to positive control. Hemorrhagic and exudate were present in villus. In the group of SSP II, villus, lamina propria, and epithelial cell structure are better than other treatments. While hemorrhagic in villus decreased, whereas the exudate remains present on villus terminal.

\section{DISCUSSION}

Black cincau supplement has higher antioxidant activity than its raw material due to bioactive compounds extracted from black cincau and red ginger which enhances antioxidant activity of the supplement $[24,25]$. Antioxidant compounds extracted from plant can inhibit cell damaged through preventing oxidative stress and can be used for immunostimulant [26-28]

The cellular immune system is an immune system that produced from $\mathrm{T}$ cell. CD4+ T cells proliferate to TFH (T Follicular Helper), Th1 (Thelper 1), Th2, Th9, Th17, and Th22 for trapping antigen in macrophage expressed through MHC II (Major Histocompatibility Complex) [1]. The elevation of the immune system occurs due to the activation of $\mathrm{CD}^{+} \mathrm{T}$ cells, leading to the low level of $\mathrm{CD} 4^{+} \mathrm{T}$ cells in the mouse spleen induced by the bioactive compounds in the supplement (SSP II). The combination of black cincau, pandan leaves, and red ginger provides a synergic effect shown by the increased levels of phenol and antioxidant activity [29]. $\mathrm{CD}^{+} \mathrm{T}$ cells kill the infected cells in MHC I antigen presented by antigen presenting cell (APC). Tc (cytotoxic cell) cells generate Th1 and Th2 cytokine, TNF- $\alpha$, perforin, and apoptosis leading to cytolisis [1]. Mice condition approaching recovery and presence of phenol in the supplement. Low levels of a relative average of $\mathrm{CD}^{+} \mathrm{T}$ cells in SSP II and SK occurred due to the activation of lymphocyte in the infected cells. CD8 T cells were activated by the supplement to support bacteria phagocytosis. Low levels of CD4 ${ }^{+} \mathrm{CD} 8+\mathrm{T}$ cells on SSP II and SK occurred due to differentiated cells to form CD4 and CD8 cells. The low levels of $\mathrm{CD}^{+} \mathrm{CD}^{+} \mathrm{T}$ cells were followed by the high number of differentiated cells to form CD4 and CD8 T cells. IFN- $\gamma$ stimulated expression of MHC I and MHC II, co-stimulator APC, enhanced differentiation of $\mathrm{CD}^{+} \mathrm{T}$ cells, microbe phagocytosis, neutrophil activation, and stimulated cytolitic effects of NK cells [1].

CD62L is a protein expressed in B cells, T cells, monocyte and NK cells [1]. Expression of CD62L protein in CD4 T cells showed CD4 T cells
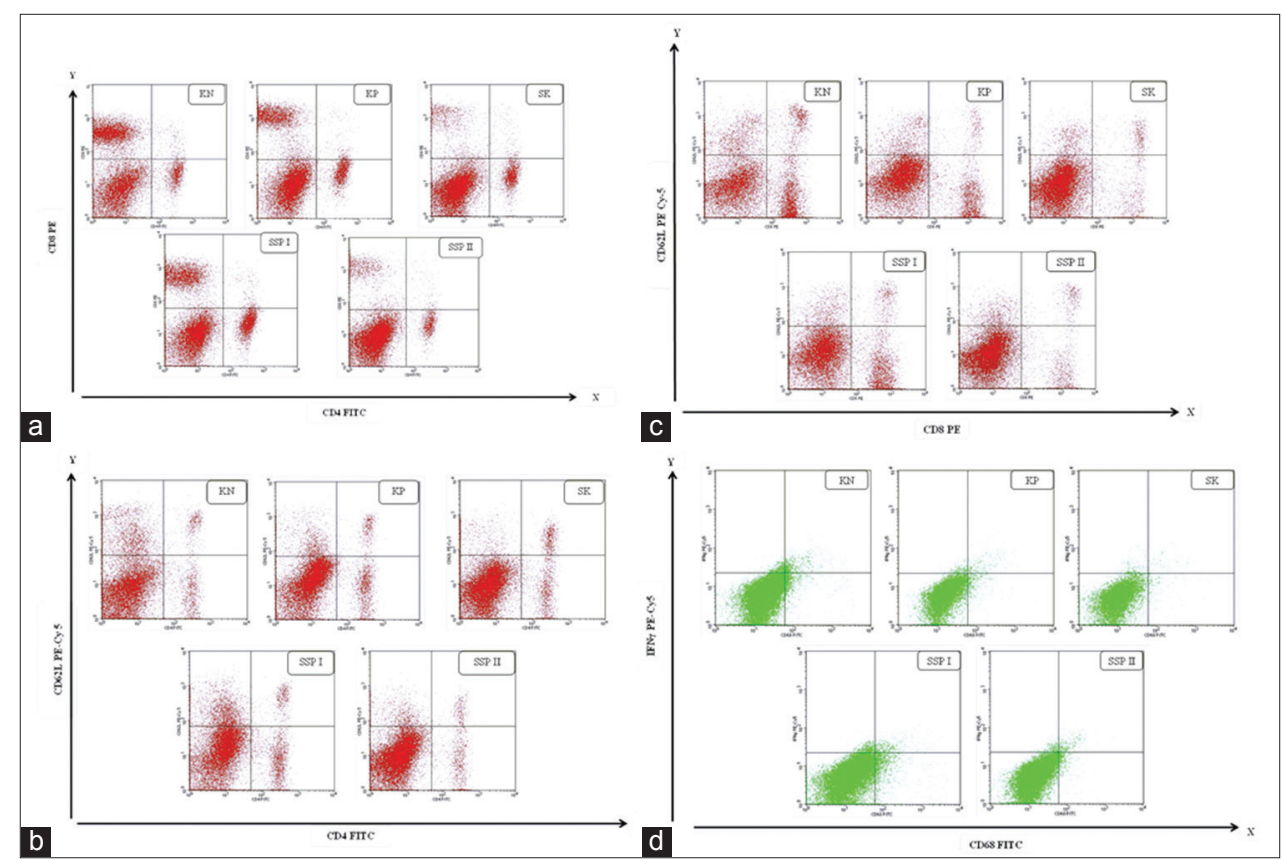

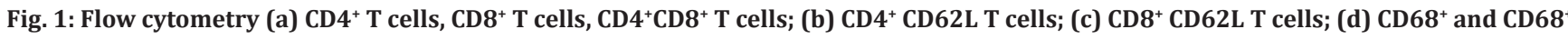
interferon-g monocyte cells 


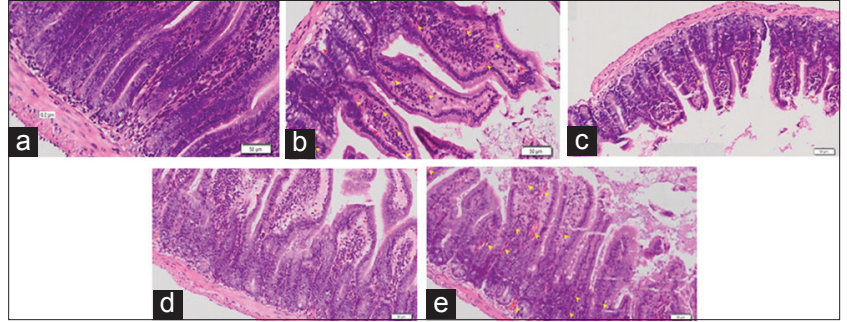

Fig. 2: Histopathology of the small intestine of mice; (a) negative control, (b) positive control, (c) SSP I, (d) SSP II and (e) SK. A yellow arrow $(>)$ indicating hemorrhagic, red arrow $(\gg)$ indicating exudate in the small intestine walls. The thickness of the small intestine mucous in healthy mice was $0.2 \mu \mathrm{m}$ whereas the infected mice was $0.1 \mu \mathrm{m}$

were naive [30]. Percentage of naïve $\mathrm{CD} 4^{+} \mathrm{T}$ cells in infected mice lamina propria was higher than the healthy ones [31]. $\mathrm{CD} 8^{+} \mathrm{T}$ cells which binds CD62L protein are naïve cells. This result showed the high presence of CD8 T cells expressed to recover immune system of infection compared to $\mathrm{CD}^{+} \mathrm{T}$ cells. $\mathrm{CD} 8^{+} \mathrm{T}$ cells are cytotoxic $\mathrm{T}$ cells damaging bacteria infected cells in MHC I antigen presented by APC [1].

CD68 protein is a surface marker expressed by macrophage but not specifically [32,33]. CD68 IFN $-\gamma$ monocyte showed IFN $-\gamma$ intracellular produced by CD68 monocyte cells, but not secreted form cell. The macrophage is non-specific immune system, which is initial immune on infection in within 0-12 hrs [1]. In this study, the supplement was orally given for 7 days after E. coli infection. Group of SSP II has the ability to stimulate macrophage producing IFN- $\gamma$ which can be used in cell differentiation of CD4 T cells, CD8 T cells, and B220 B cells indicated by recovery level in mice. Aqueous extract of black cincau at a dose of $1000 \mathrm{mg} / \mathrm{kg}$ b.w increased the level of IFN- $\gamma$ in the early infection [10].

Histopathology examination of small intestine aimed to see the damaged cell caused by intra-peritoneal injection of E. coli strain 0157 and to determine the effects of black cincau and red ginger exposure on the damaged cells in infected mice. Small intestine adapts in the gastrointestinal tract and a nutrition adsorption [34]. Injection of $E$. coli in mice caused shedding and necrosis of villi and epithelial cells in the small intestine due to the reaction of Stx (Shiga toxin) with an epithelial enterocyte in the gastrointestinal tract [35]. Hemorrhagic in villus and an exudate in the small intestine occurs in infected mice. Exudate is liquid emerged from vein caused by the low capillary permeability and pressure on the capillary wall [36]. An exudate in the small intestine indicates an improvement of mice health. Davies [37] reported the quantity of exudates depends on wounds and its recovery level. Positive control showed a good recovery in villus, lamina propria, and mucous compared to negative control, but not as good as on exposure of SSP II due to the high occurrence of hemorrhagic in villus. Group of SSP II showed a significant result in recovery of mucous structure in Escherichia coli strain 0157-infected mice.

\section{CONCLUSION}

Exposure of black cincau supplement at a dose of $43.29 \mathrm{mg} / \mathrm{kg}$ b.w in E. coli infected mice increased the relative percentage of $\mathrm{CD} 4^{+} \mathrm{T}$ cells, $\mathrm{CD}^{+} \mathrm{T}$ cells, and $\mathrm{CD} 4^{+} \mathrm{CD} 8^{+} \mathrm{T}$ cells. Exposure of cincau supplement at a dose of $85.58 \mathrm{mg} / \mathrm{kg}$ b.w increased activation of $\mathrm{CD}^{+} \mathrm{T}$ and $\mathrm{CD} 8^{+} \mathrm{T}$ cell percentage, increased IFN-g in CD68 monocyte cells, and recovered the structure of mice small intestine mucosa.

\section{ACKNOWLEDGMENTS}

This work was supported by Special Research for University Project 2014, Directorate General of Higher Education Ministry of Education Republic of Indonesia, University of Brawijaya Annual Budget. Rector Decree, Number: 157/SK/2014 date, 10 April 2014.

\section{REFERENCES}

1. Baratawidjaja KG, Rengganis I. Basic Immunology. $10^{\text {th }}$ ed. Jakarta: Faculty of Medicine, Indonesia University; 2013.

2. Munasir Z. Immune response on bacterial infection. Sari Pediatr 2007;2:193-7.

3. Kuntz TB, Sean TK. Enterohemorraghic E. coli infection. Fourth Prize Pap 1999;6 Suppl 6:192-6.

4. Byrd W, Mog SR, Cassels FJ. Pathogenicity and immune response measured in mice following intranasal challenge with enterotoxigenic Escherichia coli strains H10407 and B7A. Infect Immun 2003;71:13-21.

5. McGhee JR, Mestecky J, Dertzbaugh MT, Eldridge JH, Hirasawa M, Kiyono H. The mucosal immune system: From fundamental concepts to vaccine development. Vaccine 1992;10:75-88.

6. Byrd W, Cassels FJ. Mucosal immunization of BALB/c mice using enterotoxigenic Escherichia coli colonization factors CFA/I and CS6 administered with and without a mutant heat-labile enterotoxin. Vaccine 2003;21(17-18):1884-93

7. Sasmito E, Nunung Y, Soegihardjo CJ. The immunomodulatory mechanism extract of mengkudu (Morinda Citrifolia, $L$.) fruit on mice $\mathrm{Balb} / \mathrm{C}$ induced by hepatitis b vaccine. Tradit Med J 2008;13(43):1-8.

8. Gertsch J, Viveros-Paredes JM, Taylor P. Plant immunostimulants - Scientific paradigm or myth? J Ethnopharmacol 2011;136(3):385-91.

9. Ruhnayat A. Black cincau Medicine Plants. Jakarta: Penebar Swadaya Publisher; 2002.

10. Widyaningsih TD, Sukardiman, Purwanto DA, Darmanto W. Immunomodulatory effects of black cincau water extract (Mesona palustris BL) on carcinogenesis mice. J Technol Food Ind 2012;23 Suppl 1:31-7.

11. Ahmed RS, Sharma SB. Biochemical studies on combined effect of garlic (Allium sativum Linn) and ginger (Zingiber officinale Rosc) in albino rats. Indian J Exp Biol 1997;35(8):841-3.

12. Malipatil NB, Manjunath S, Shruthi DP. Evaluation on effect of aqueous extract of Zingiber Officionale Roscoe (Ginger) on acute and chronic inflammation in adult albino rats. Asian J Pharm Clin Res 2015;8(2):113-6.

13. Henarti, Winarti C. Bioactive compounds of ginger and its benefits in medicine. Balai besar penelitian dan pengembangan pascapanen pertanian. Status Teknol Hasil Penelitian Jahe. Bogor: Balai Besar Penelitian dan Pengembangan Pascapanen Pertanian; 2012

14. Suekawa M, Ishige A, Yuasa K, Sudo K, Aburada M, Hosoya E. Pharmacological studies on ginger. I. Pharmacological actions of pungent constituents, (6)-gingerol and (6)-shogaol. J Pharmacobiodyn 1984;7(11):836-48.

15. Kim DS, Kim DS, Oppel MN. Shogaols from Zingiber officinale protect IMR32 human neuroblastoma and normal human umbilical vein endothelial cells from beta-amyloid(25-35) insult. Planta Med 2002;68(4):375-6.

16. Sekiya K, Ohtani A, Kusano S. Enhancement of insulin sensitivity in adipocytes by ginger. Biofactors 2004;22(1-4):153-6.

17. Schmid R, Schick T, Steffen R, Tschopp A, Wilk T. Comparison of seven commonly used agents for prophylaxis of seasickness. J Travel Med 1994;1(4):203-6.

18. Widyaningsih TD, Mahar J, Wijayanti N, Rahmani, Najmuddin M. Immunomodulatory effect of instant tea powder from black cincau (Mesona palustris $\mathrm{BL}$ ) in the treatment of Salmonella typhimurium induced infection in balb mice. Food Public Health 2013;3(3):142-6.

19. Widyaningsih TD. Cytotoxic effect of water, ethanol, and ethyl acetate extract of black cincau (Mesona palustris BL) againts HeLa cell culture. APCBEE Proc 2012;2:110-4

20. Prasetyo G, Zumroh IZ, Etikasari M, Wajdi RF, Widyaningsih TD. Formulation of black grass jelly effervescent powder with addition of pandan leaf and red ginger. J Pangan Agroindustri 2015;3(1):90-5.

21. Widyaningsih TD, Widjanarko $\mathrm{S}$, Waziiroh $\mathrm{E}$, Wijayanti $\mathrm{N}$, Maslukhah YL. Pilot Plant Scale Extraction of Black Cincau (Mesona palustris BL) using Historical-Data Response Surface Methodology. Research Report. Faculty of Agricultural Technology: Brawijaya University; 2015.

22. Hatano T, Edamatsu R, Hiramitsu M, Mori A, Fujita Y, Yasuhara T, et al. Effect of the interactions of tannins with co-existing substances. VI. Effect of tannins and related polyphenols on superoxide anion radical and on 1,1-diphenyl-2-picrylhidrazil radical. Chem Pharm Bull 1989;37(8):2016-21.

23. Zumrotul M, Rifai M, Rahayu S. Immunomodulator activity of Morinda citrifolia extract on Staphylococcus aureus infected mice. Vet J 2013;14(4):501-10 
24. Maslukhah YL. Optimization of Extraction of Raw Material of Black Cincau Supplement (Mesona palustris BL) on a Pilot Plan Scale in PT ASIMAS Jawa Timur. Thesis. Department of Agricultural Product Technology. Faculty of Agricultural Technology: Brawijaya University; 2015.

25. Maslukhah YL, Widyaningsih TD, Waziroh E, Wijayanti N, Sriherfyna FH. Effects of black Cincau extraction (Mesona palustris BL) on a pilot plant scale: Literature study. J Food Agroind 2016;4(1):245-52

26. Aher VD, Wahi A, Pawdey AM, Sonawane A. Antioxidants as immunomodulator: An expanding research avenue. Int J Curr Pharm Res 2011;3(1):8-10.

27. Bhadoriya SS, Singh S, Mangal A, Mandoriya N. Immunomodulatory effect of M. tricuspidatum. Int J Curr Pharm Res 2012;4(2):33-6.

28. Gayatri N, Sahu RK. Immunostimulatory effect of Ocimum sanctum Linn. Leaf extract in Clarias batrachus Linn. Asian J Pharm Res 2014;7(3):157-63

29. Prasetyo G, Zumroh IZ, Etikasari M, Wajdi RF, Widyaningsih TD. Effervecent formulation based on black Cincau, pandan leaves, and red ginger. J Food Agroind 2015;3(1):90-5

30. Spadaro M, Caldano M, Marnetto F, Lugaresi A, Bertolotto A. Natalizumab treatment reduces L-selectin (CD62L) in CD4 T cells. J Neuroinflammation 2015;12:146.
31. Heimesaat MM, Bereswill S, Fischer A, Fuchs D, Struck D, Niebergall $\mathrm{J}$, et al. Gram-negative bacteria aggravate murine small intestinal Th1-type immunopathology following oral infection with Toxoplasma gondii. J Immunol 2006;177(12):8785-95.

32. Gregorio GB, Yao-Borengasser A, Rasouli N, Varma V, Lu T, Miles LM, et al. Expression of CD68 and macrophage chemoattractant protein-1 genes in human adipose and muscle tissues: Association with cytokine expression, insulin resistance, and reduction by pioglitazone. Diabetes 2005;54(8):2305-13.

33. Harris JA, Jain S, Ren Q, Zarineh A, Liu C, Ibrahim S. CD163 versus CD68 in tumor associated macrophages of classical Hodgkin lymphoma. Diagn Pathol 2012;7:12.

34. Tso PP, Crissinger K. Overview of digestion and absorption. In: Stipanuk MH, editor. Biochemical, Physiological, and Molecular Aspects of Human Nutrition. USA: Saunders, Elsevier; 2006. p. 151-66.

35. Saleh SM, Ahmed MF, Hadi SA. Effect of oral Sacchromyces boulardii treatment againts experimental infection with enterotoxigenic $E$. coli in mice. J Al-Nahrain Univ 2014;17(1):109-13.

36. Harding K. Principles of Best Practice: Wound Exudate and the Role of Dressing - A Consensus Document. London: Medical Education Partenership (MEP) Ltd.; 2007.

37. Davies P. Exudate assessment and management. Br J Community Nurs 2013;17(9): S18-S24 